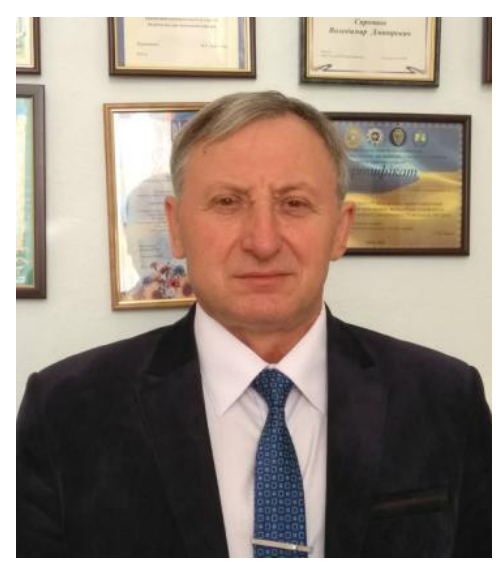

\author{
Микола Чумак, \\ кандидат педагогічних наук, доцент кафедри теорії \\ та методики навчання фрізики та астрономії, \\ Національний педагогічний університет \\ імені М.П. Драгоманова \\ (м. Київ, Україна) \\ Mykola Chymak, \\ $\mathrm{PhD}$ in Education, Associate professor Department of \\ Theories and Methods of Teaching Physics and Astronomy, \\ of National Pedagogical Dragomanov University (Kiev, \\ Ukraine) \\ chumak.m.e@gmail.com
}

ORCID ID 0000-0002-9956-9429

удк 373.5[37:01]

\title{
SOCIO-CULTURAL MEASURES OF EDUCATION DEVELOPMENT IN THE TERRITORY OF GALICIA AND NADDNIPRYANSHCHYNA (XVIII - XIX CENTURIES)
}

Abstract. The article deals with the fundamental activity of progressive representatives of Ukrainian educators of a certain epoch on the way to achieving socio-cultural optimum.

The rethinking of the acute need for Ukraine to enter the European educational space has actualized the author's task - a deep retrospective reconsideration of the historical and pedagogical events of previous centuries, with a view to interpret more thoroughly the experience of the Enlighteners of the past generations and define their general significance for the further development of our state.

The purpose of the article is to reveal the socio-cultural dimensions of the development of education in the territory of Galicia and Naddnipryanshchyna in the context of the XVIII - XIX centuries. The author investigates the multidimensionality of the main directions and forms of work of education and science representatives during the studied historical period.

The research tools for the study were chronological and content, incremental, historical, pedagogical and comparative methods. The use of a whole range of methodological research tools allowed to determine that the activities of the progressive scientific and educational elite of the time, which continued to widely disseminate high-education ideas on the pro-Ukrainian territory, became the basis for more advanced development of vocational education.

Keywords: socio-cultural development, education, territory, Galicia, Naddnipryanshchyna.

\section{СОЦІОКУЛЬТУРНІ ВИМІРИ РОЗВИТКУ ОСВІТИ НА ТЕРИТОРІЇ ГАЛИЧИНИ ТА НАДДНІПРЯНЩИНИ (XVIII - XIX СТ.)}

Анотація. У статті розглянуто фундаментальну діяльність прогресивних представників українських освітян визначеної епохи на шляху до досягнення соціокультурного оптимуму.

Переосмислення гострої необхідності входження України до Європейського освітнього простору актуалізувало авторське завдання - здійснити глибинний ретроспективний аналіз історико-педагогічних подій попередніх століть 3 метою більш ґрунтовного переосмислення досвіду світочів минулих поколінь із визначенням їх загальної значущості для подальшого розвитку нашої держави.

Метою статті є розкриття соціокультурних вимірів розвитку освіти на території Галичини та Наддніпрянщини у розрізі XVIII - XIX ст. Автор досліджує багатоаспектність основних напрямів і форм роботи представників освіти та науки досліджуваного історичного періоду.

Інструментарієм дослідження виступив історико-педагогічний, поетапно-проблемний, хронологічно-змістовний та порівняльний методи.

Використання низки методологічного інструментарію дозволило визначити, що діяльність прогресивної науковопедагогічної еліти того часу, яка продовжувала поширювали на проукраїнській території просвітницькі ідеї, стала базовою основою для більш поглибленого розвитку професійної освіти. 
Систематичні дослідження з кінця XVIII ст. До середини XIX ст. Вітчизняні педагоги цього періоду почали активно вивчати територію України. Плідні результати наукової роботи імперського уряду співвідносяться з політичною ідеєю активних пошуків регіональної та української відокремленості. Водночас розвиток освіти на території Галичини і Наддніпрянщини був досить неоднорідним. Такий хід подій випливав із специфіки соціокультурного розвитку регіонів, рівня розвитку науки і освіти. В регіональних умовах представники вітчизняної інтелігенції працювали над розвитком освіти, що згодом дало поштовх до відновлення незалежності України. Зростання кількості тематичної літератури вплинуло на процес демократизації уявлень про зміст історії та сприйняття вчених, які вивчали їхній регіон. Таким чином, поширення освітніх і природничо-наукових ідей відбувалося не лише в кількох регіонах, а й на всій території України.

Ключові слова: соціокультурний розвиток, освіта, територія, Галичина, Наддніпрянщина.

\section{INTRODUCTION}

Formulation of the problem. Productive development of science and education actualizes the issue of historical and pedagogical realities interpretation, which reproduce the key educational tasks of various historical epochs. In this aspect, the object of research is education and the educational process, which possesses cultural content, and its subject are certain personal transformations, which provide an indication of the smooth transition of consciousness from sensual to a real rethinking of dialogue with the world and culture as a whole.

The selected problem still requires a more comprehensive scientific rethinking, as evidenced by the fragment nature of a number of historical and pedagogical content studies.

An outline of the particular aspects of the stated problem is found in the works of V. Andrushchenko, V. Syrotyuk, A. Sukhomlynska, T. Zavgorodnya, T. Dudka, and others. However, the study of socio-cultural dimensions of regional development of education in the light of certain historical epochsrequiresa deeper analysis.

THE PURPOSE of the article is to reveal the socio-cultural dimensions of the development of education in the territory of Galicia and Naddnipryanshchyna in the context of the XVIII - XIX centuries.

According to the purpose, the main objectives of the study are defined as the following:to analyze the state of the investigated problem;to investigate the influence of the subject of research on the socio-cultural development of the regions;to popularize the existing educational experience in the current conditions of Ukraine's development.

RESEARCH METHODS: chronological and content, incremental, historical, pedagogical and comparative.

\section{RESEARCH RESULTS}

The population of western regions of Ukraine during the studied period was under the control of the Polish nobles (XVIII century), possessing certain regional knowledge, although it was not taught in educational institutions. According to I. Franko, everyone «should have known about the vast expanses of his country ...», regardless of the fact that at that time ethnography «was not studied from books», but functioned thanks to the system of oral retelling [10, p. 118]. Russian researcher S. Krashennikov noted that the main task of science in the XVIII century was to study own region «in all its borders, the wealth of each territorial unit, the craft of citizens and subordinate people, customs and ceremonies, etc.» [11, p. 6].

Systematic researches from the end of XVIII century to the middle of XIX century were closely associated with the Baroque, which went into the Romantic Era. The Baroque style was rather tempting for the Ukrainian society that was between the Latinized West and the Orthodox East. Domestic educators of this period began to explore actively the territory of Ukraine. The fruitful results of the scientific work of the imperial government correlate with the political idea of active searches for regional and Ukrainian separateness. Their achievements were not only recognized, moreover

- they were seen as valuable material that could be used in the educational process. At the beginning of the XVIII centuries, new disciplines, filled with natural sciences content, were incorporated in the program of the Kyiv-Mohyla Academy. Geography, as an independent subject, was separated from other courses of natural philosophy, and later the geographichistorical class was formed. The educational process of the newly-formed class involved many natural science materials, which the scientific developments of teacherscontained. Theodosius Sofonovych, in his work, «The Chronicle» noted that every pupil «... needs to know about his fatherland and to others, asking, to tell, because people without this knowledge are taken as dishonorable ones» $[12$, p. 35].

In the second half of the XVIII century, Epiphany Slavynetskyi and Arseniy Satanovskyi translated the work of German geographer A.-F. Büşing «Magazin fir nene Historie und Geographie» (1765-1793). This work contained a lot of descriptions of the Kyiv region and other regions of Ukraine [13, p. 94].

Sylvester Kraisky, professor of the Academy, translated from Italian the book «Cosmographic epitome, or an easy entry to astronomy, geography and hydrography, collected for a comfortable understanding of globes, plan spheres, astrolabes and geographic maps». The above mentioned work contained detailed instructions on how to explore a particular area with visual means. The systematized works of German diplomat Sigismund Gerberstein «Notes on Muscovy», as well as Sebastian Munster's «Cosmography» were used in the educational process of the Kyiv-Mohyla Academy. The works provided short descriptions of the flora and fauna features of the regions of Ukraine.

Since 1799, at the academy, an extraordinary class of rural and domestic economics was opened. Studying in this class, the youth studied in detail the basic methods of farming on the territory of the region. Students' acquaintance with practical aspects of activity included such components as the basics of arable farming, fishing, horticulture, livestock farming, beekeeping, etc.

The German scholar H. Hegelmayer, analyzing the educational process that functioned at the Kyiv-Mohyla Academy, said: «... in the Cossack souls, the aspiration for higher and better deeds and wise knowledge of own land is growing» [11, p. 97]. The words of the researcher reveal the whole depth of the Cossacks' ideal, which, 
interwoven with the regional knowledge, formed the general view of the high level of education of that time students. The educational process in the Academy was based not only on the knowledge that the students received by studying various disciplines. At that time, progressive educators understood education as «... means of forming a national consciousness, patriotic feelings, a civil responsibility to the land and the homeland ...» [13, p. 122]. A well-established educational system in the Kyiv-Mohyla Academy was also reflected in the activities of graduates. After ten years of study at the academy, graduate student Andriy Samborskyi published a scientific work entitled «Description of Practical Agriculture» (1781) and a manual «Regulations of the Practical School of Arable Farming and Agriculture» (1798). In 1804, Samborskyi organized the opening of a school in which the pupils studied the rules of agriculture in the territory of their native land.

Another graduate of the Academy, Petro Prokopovych, first invented a frame beehive, which enabled to obtain pure honey without destroying bees. In 1828, Prokopovych organized the first in Europe school of beekeeping near Baturyn. The training in it consisted of two components - theoretical and practical ones, which combined the study of honey-yielding plants of the region, the beeforage and new means of bees' treatment. Over half a century of its existence, the school has trained more than 600 professionals. Considering the personality of P. Prokopovich in the historical aspect, modern teachers point out that «... the history of beekeeping after Aristotle has not known such a person» [13, p. 99].

Jesuit colleges and schools operated in the Right-bank Ukraine, which showed a tendentious policy regarding the achievements of the Ukrainian people, their customs, culture, traditions and natural sciences achievements as a whole.

In 1788, teachers of the fourth grade were instructed to commence the formation of a commission, together with the directors of educational institutions, «... for a proper description of the general condition of the province ... with the indication of the number of seminaries ... to describe the characteristics of the people according to their customs and traditions ...» [1, p. 55] as noted in the «Archive of Southwestern Russia».

G. Skovoroda equated the study of the features of his area with a living book and called: «Read it always and learn, as if from the high harbor look at the devastating ocean, and have fun» [8, p. 41]. In this way the teacher depicted an inexhaustible ocean of native history, which is to be studied systematically, throughout all life.

The development of education in the territory of the Left Bank of Ukraine was due to the fundamental activity of the traveling teachers, who were the clerks. In the study, they used sources of folk art and local lore materials, which, from the very early childhood, cultivate in children love for their native land.

The writer Fedir Tumansky was the author of questionnaire programs for collecting geographical, historical, economic, ethnographic, and anthropological information on the territory of the Left-Bank Ukraine. Not only adults but also children were involved in the research. The artist organized excursions to study different regions of Ukraine. As a result, natural and geographical descriptions of localities and scientific works devoted to the history of their foundation were published. In addition, F. Tumansky was the first to organize the publication of Russian chronicles [3, p. 67].

In 1791, the Moscow Magazine provided information on the level of interest in the local material, «... the population is interested in everything: the peculiarities of one or another region, finding the slightest differences in the way of life of their inhabitants; monuments that awaken in their memory various memorable dates; traces of people who have not been in the world for a long time ...» [6, p. 295]. The above quotation serves as a vivid example of practical implementation of ethnography in the socio-cultural space.

During the XIX century, a wide range of profile literaturewas presented to the services of those who wished to study and perfectly know their native spaces. The genres of the travel impressionsdescriptions, guides, records about ancient monuments, statistical descriptions, etc have become especially popular. The growth of the amount of thematic literature influenced the process of democratization of ideas about the content of history and the perception of the scientists who studied their region.

At the beginning of the XIX century, educational institutions have advanced the issue of expanding the direction of educational work with students by involving them in local material collecting. In one of the statutes of the Gymnasium (1804) it was noted that the pupils «... are obliged to collect herbs in their area, various stones and to find out their properties and certain features» $[5$, p. 322].

Famous Ukrainian teacher, director of the Kyiv Gymnasium - Maxim Berlinskyi collected a lot of data on his native land, which he presented in the following works - «The History of Kyiv City» (1798-1799) and «A Brief Description of Kiev, containing the historical catalogue of this city» (1820).

The work «Topographic description of Poltava Gymnasium by Fyodor Karunovsky» (1809) is considered to be one of the earliest thematic studios. The following information can be found about this author we: «The climate, soil, flora, fauna are issues of his interest. In search of answers he often travelled to the counties as a researcher of the region» [9, p.17].

The best and most accurate guide to studying Ukraine in the first half of the XIX century was the four-volume work of Dmitry Bantysh-Kamenskyi «History of Little Rus», published in 1822.

The guardian of the Nizhyn Gymnasium of the highest science A. Kuleshov-Bezborodko was the first in Chernihiv region who proposed to organize a scientific society at the gymnasium, which would be engaged in conducting regional studies. However, the teachers did not support this proposal, explaining their decision by the fact that the institution was small and they were engaged in rational adjustment of the educational process. In the minutes of the conference of the Gymnasium of the highest science dated February 10, 1822, it was noted that the «sources» of studying the land were chronicles, folk tales, songs, letters, and other materials from which credible data could be taken [7, p. 192]. 
In 1827, the first regional newspaper «Odessa Gazette» was published in the southern region of Ukraine. During the period from 1828 to 1860,250 articles of natural science content were published, sponsored by teachers, officials, clergy and landlords living in Kherson, Tavria and Katerynoslav provinces.

It is not difficult to see that the spread of educational and natural science ideas took place not only within the several regions, but also throughout the territory of Ukraine.

In the second half of the XVIII century - the first quarter of the XIX century, Mukachevo bishops Ivan Bardach and Andriy Bachinskyi led a new cultural center in the Transcarpathia. This site was engaged in the collection of thematic materials, and ensured that the collected data was included in the educational process. That is why the bishops prepared for printing and published educational materials - primers and textbooks, the content of which was based on the eternal values of the native land beauty and love for it.

\section{CONCUSSION AND PROSPECTS FOR FURTHER RESEARCH}

In view of the foregoing, it can be concluded that the development of education in the territory of Galicia and Naddnipryanshchyna was quite heterogeneous. Such course of events resulted from the specifics of socio-cultural development of the regions, the level of development of science and education. Under regional conditions, representatives of the domestic intelligentsia worked on the development of education, which eventually gave impetus to the restoration of Ukraine's independence later on. Prospects of the further researches are seen in the study of pedagogical personnel's of the given epoch on the basis of regional aspect.

\section{СПИСОК ВИКОРИСТАНИХ ДЖЕРЕЛ}

[1] Артоболевский Б. В. К истории краеведческих замыслов М.В. Ломоносова. Краеведение. 1926. Т. III. С.55.

[2] Бабишин С. Д. Краеведение как средство связи с жизнью и підготовки учащихся к труду: автореф. дис. на соискание науч. степени канд. пед. наук: спец.13.00.04. «Теория и методика професионального образования». М., 1963. 21 с.

[3] Белозерская Н. Исторический журнал XVIII века. Журнал Министерства народного просвещения. 1898. № 1. С. 64 - 84.

[4] Дудка Т. Ю. Просвітницький туризм як історико-педагогічний феномен: [монографія]. Київ-Херсон : ФОП Гринь Д.С., 2017.460 с.

[5] Історія української школи і педагогіки: Хрестоматія / Упоряд. О. О. Любар; за ред.

В. Г. Кременя. К.: Т-во «Знання», 2003.766 с.

[6] Карамзин Н. М. Письма руського путешественника. М., 1982. 318 с.

[7] Лавровский Н. А. Гимназия высших наук кн. Безбородко в Нежине. Известия Историко-филологического института кн. Безбородко в Нежине. Нежин, 1879. Т. 3. С. 192.

[8] Май К. В. Первая екскурсія ученикові Ченстоховской мужской гимназіи въ Кіевъ, Одессу и Крымъ (10 - 26 июня 1904 года). К., 1906. 59 c.

[9] Описи Лівобережної України кінця XVIII - початку XIX століття. К., 1997. 118 с.

[10] Франко І. Галицьке краєзнавство. Зібрання творів: У 50-ти томах. К., 1986. Т. 46. Кн. 2. С. 118.

[11] Хегельмайєр Х. Повідомлення про стан ученості у Києві в російській Україні. Київська старовина.1994. № 2. С. 95-99.

[12] Хижняк 3. І. 3 історії Києво-Могилянської академії XVII -XVIII ст. К.: Вид. дім «Києво-Могилянська академія», 2005. 64 с.

[13] Хижняк 3. І. Історія Києво-Могилянської академії. К.: Вид дім «Києво-Могилянська академія», 2008. 203 с.

\section{REFERENCES (TRANSLATED AND TRANSLITERATED)}

[1] Artobolevskyj B. V. K ystoryjy kraevedcheskyh zamuslov M.V. Lomonosova (To the history of local lore concepts of M.V. Lomonosov). Kraevedenyje. 1926. T. III. S.55. (in Russian)

[2] Babyshyn S. D. Kraevedenye kak sredstvo svyazy s zhyznyu y podgotovky uchashhyhsya $\mathrm{k}$ trudu (Local studies as means of communication with the life and students preparation for work). Avtoref. dys. na soyskanyenauch. stepeny kand. ped. nauk: specz.13.00.04. «Teoryja y metodyka profesyonalnogo obrazovanyja». M., 1963. 21 s. (in Russian)

[3] Belozerskaya N. Ystorycheskyj zhurnal XVIII veka (Historical journal of the XVIII century). Zhurnal Mynysterstva narodnogo prosveshhenyja. 1898. №1. S. 64 - 84. (in Russian)

[4] Dudka T. Yu. Prosvitnyczkyj turyzm yak ystoryko-pedagogichny pfenomen (Educational tourism as a historical and pedagogical phenomenon). Kyiv-Herson : FOP Gryn D.S., 2017. 460 s. (in Ukrainian)

[5] Ystoriya ukrayinskoyi shkoly i pedagogiky: Hrestomatiya (History of the Ukrainian school and pedagogy). Uporyad. O. O. Lyubar; za red. V. G. Kremenya. K.: T-vo «Znannya», 2003. 766 s. (in Ukrainian)

[6] Karamzyn N. M. Pysma ruskogo puteshestvennyka (Letters of the Russian traveler). M., 1982. 318 s. (in Russian)

[7] Lavrovskyj N. A. Gymnazyja vusshyh nauk kn. Bezborodko v Nezhyne (Gymnasium of the highest sciences of duchess Bezborodko in Nizhyn). Yzvestyja Ystoryko-fylologycheskogo ynstytuta kn. Bezborodko v Nezhyne. Nezhyn, 1879. T. 3. S. 192. (in Russian)

[8] Maj K. V. Pervaya ekskursiya uchenykov Chenstohovskoj muzhskoj gymnaziy v Kyiv, Odessu y` Krum (10 - 26 yjunya 1904 goda) (The first tour of the Chenstokhow male gymnasium students to Kyiv, Odesa and Crimea (June $10-26,1904$ ). K., 1906. 59 s. (in Russian)

[9] Opysy Livoberezhnoyi Ukrayiny kincya XVIII - pochatku XIX stolittya (Descriptions of the left-bank Ukraine of the end of XVIII - the beginning of the XIX century). K., 1997. $118 \mathrm{~s}$. (in Ukrainian)

[10] Franko I. Galyczke krayeznavstvo (Galician regional studies). Zibrannyatvoriv: U 50-ty tomax. K., 1986. T. 46. Kn. 2. S. 118. (in Ukrainian)

[11] Hegelmajyer H. Povidomlennya pro stanuchenosti u Kyjeve v rosijskij Ukrajny (Report on the state of scholarship in Kiev in Russian Ukraine). Kyjivska starovyna. 1994. № 2. S. 95-99. (in Russian)

[12] Hyzhnyak Z. I. Z ystoriyi Kyjyevo-Mogylyanskoj akademij XVII -XVIII st.(From the history of the Kyiv-Mohyla Academy of XVII-XVIII centuries). K.: Vyd. dim «Kyjevo-Mogylyanska akademija», 2005. 64 s. (in Ukrainian)

[13] Hyzhnyak Z. I. Ystoriya Kyjevo-Mogylyanskoyi (History of the Kyiv-Mohyla Academy).K.: Vyd dim «Kyjevo-Mogylyanska akademiya», 2008. 203 s. (in Ukrainian) 